\title{
The Concept of Bureaucracy by Max Weber
}

\author{
Sandro Serpa ${ }^{1}$, Carlos Miguel Ferreira $^{2}$ \\ ${ }^{1}$ Department of Sociology, Faculty of Social and Human Sciences, University of the Azores, Portugal; Interdisciplinary \\ Centre of Social Sciences - CICS.UAc/ CICS.NOVA.UAc; Interdisciplinary Centre for Childhood and Adolescence - \\ NICA - UAc, Portugal \\ ${ }^{2}$ Interdisciplinary Centre of Social Sciences-CICS.NOVA; Polytechnic Institute of Castelo Branco; Estoril Higher \\ Institute for Tourism and Hotel Studies, 1069-061 Lisbon, Portugal \\ Correspondence: Sandro Serpa, University of the Azores, Faculty of Social and Human Sciences, Department of \\ Sociology, Ponta Delgada, Portugal. Email: sandro.nf.serpa@uac.pt
}

Received: November 26, 2018

Accepted: January 14, $2019 \quad$ Available online: January 18, 2019

doi:10.11114/ijsss.v7i2.3979

URL: https://doi.org/10.11114/ijsss.v7i2.3979

\begin{abstract}
:
Bureaucracy is a widely disseminated concept in Sociology and in Organisational Theory studies, and it currently has an image where negative aspects are often highlighted. However, for Max Weber, bureaucracy has very specific features that differ, in varied situations, from the representation and application often ascribed to this model of organisational administration. This review aims at contributing to putting forward the concept of bureaucracy as initially proposed by Max Weber, discussing it in its potentialities.
\end{abstract}

Keywords: Bureaucracy, organisation, Max Weber, organisational management model

\section{Introduction}

Despite the existence of multiple images that may be mobilised on how to look and analyse an organisation (Cunha \& Rodrigues, 2002; Ferreira, Neves, \& Caetano, 2004; Rosado, 2015; Pimentel, 2012; Filleau \& Marques-Ripoull, 2002; Souza, 2017), in modern organisations bureaucratic features are abundantly found (Giddens, 1997). This is, still today, a central concept, for good and/or for bad, in organisations theory (Florian, 2018; Filleau \& Marques-Ripoull, 2002; Fedosov \& Paientko, 2017).

However, bureaucracy is an unavoidable notion, both in common language and even in organisational analysis, even if in the critical sense (Ang, 2016). Bureaucracy, in general, is associated with very negative features of organisations, such as delays in operation, action centred on opaque standards, excessive requests for documentation, or even countless difficulties in meeting users or customers' requests (Godoi, Silva, \& Cardoso, 2017).

This review aims to contribute to presenting the concept of bureaucracy as initially proposed by Max Weber (1864-1920), discussing it in its potentialities.

\section{Bureaucracy}

Max Weber proposes the concept of Bureaucracy in a context in which he considers rationalisation of society as inevitable (Pollitt, 2008), causing a growing impersonality in the social relationship, disenchantment of the world (Aron, 1994; Giddens, 1997). In short, bureaucracy is the "phenomenon of affirmation of the rationalisation of the world" (Paiva, 2014, p. 439). Rationalisation boosted the project of modernity by enabling the application of the general principles of reason to the conduct of human problems, fostering the ability to respond to unstable environments and to manage the inherent complexity (Touraine, 1988; Clegg, 1990). Rational action aimed at controlling uncertainty; rational calculation would limit uncertainty in a world that could be controllable. Two conceptions of rationality are put forward by Weber. "Formal rationality" regards the means-end relationship and the accomplishment of practical and indisputable ends, through a precise calculation of the means adapted to the attainment of those ends. "Real rationality" concerns the increasing theoretical dominance of reality through increasingly precise and abstract concepts (Clegg, 1990).

According to Pimentel (2012), "Bureaucracy would have developed with the modern financial economy and also with: the rationalisation of law; the importance of mass phenomena; centralisation; state interventionism and the development 
of technical rationalisation" (p. 34).

Bureaucracy may be seen as being embedded in a process of formalisation, that is, a way of redefining, reinterpreting reality and reclassifying its elements, focused on increasing the capacity for control and direction, enabling the extension of the modern institutions' field of action. Formalisation, by being based on the classification «method», sorts and catalogues certain phenomena of reality by ascribing them a linguistic expression, requiring the construction of concepts that represent certain aspects of the world. Through classification tasks, the norms of inclusion and exclusion are established and possibilities for action are structured (Wagner, 1997). However, the process of modernity extension, i.e., the set of social transformations that reinsert individuals in a new order, is materialised not only through a growing formalisation, but also its standardisation and homogenisation. Conventionalisation is a means to reduce uncertainty by limiting the variation of events, actions, and interpretations that may take place. It is a collective effort to build a controllable social world. One of its aspects is to increase the possibility of understanding the social world by classifying the phenomena of society. Another aspect consists of imposing the use of these classifications to the whole society. The possibility of control cannot be increased while relevant groups operate with divergent definitions of important social phenomena. Homogenisation favours homogenising the different, imposing order and eliminating ambivalence in the name of reason and through bureaucratic control. Homogenisation of structures, cultures, and outcomes of modern institutions that seek to rationally manage the contexts in which they operate, which are characterised by uncertainty and constraint, emphasises the similarity of forms, strategies, and processes of modern institutions, aiming for legitimacy (Wagner, 1997).

\subsection{Bureaucracy for Max Weber}

Weber considers that rational domination (Cruz 1995, Giddens, 1997, Filleau \& Marques-Ripoull, 2002) based on legal legitimacy (authority based on rule or norm and procedure) (Pimentel, 2012) would assume a increasing predominance and that would be translated into bureaucracy, in what Matos and Lima (2007) consider an "elective affinity". For Weber: "Bureaucratic administration means domination by the force of knowing: that is its fundamental character, specifically rational" (Cruz, 1995, 689).

The development of the modern form of organisation concurs in all sectors with the development and continuous expansion of bureaucratic administration [...] Because the bureaucratic administration is always observed under equal conditions and from a formal and technical perspective, the most rational type [...] The main source of the superiority of bureaucratic administration lies in the role of technical knowledge, which, through the development of modern technology and economic methods in goods' production, has become absolutely indispensable [...] Bureaucratic administration fundamentally means the exercise of domination based on knowledge. This is the trait that makes it specifically rational. It consists, on the one hand, of technical knowledge, which is, per se, sufficient to ensure a position of extraordinary power for bureaucracy. On the other hand, it should be considered that bureaucratic organisations, or those in power who use it, tend to become even more powerful by the knowledge that comes from the practice that they attain in the function (Weber, 1966, pp. 24-26).

The bureaucracy presented by Weber is an ideal-type (Florian, 2018; Serpa, 2018; Ang, 2016), in the sense that it is a scheme composed of theorised features with which reality may be compared.

The bureaucratic rationality in organisations, as the model of the organisations' functioning in capitalist societies, has the characteristics depicted in Figure 1 (Ferreira, 2004; Guzmán, 2015; Florian, 2018; Faria \& Meneghetti, 2011; Ang, 2016; Pollitt, 2008; Branco, 2016; Aron, 1994). 


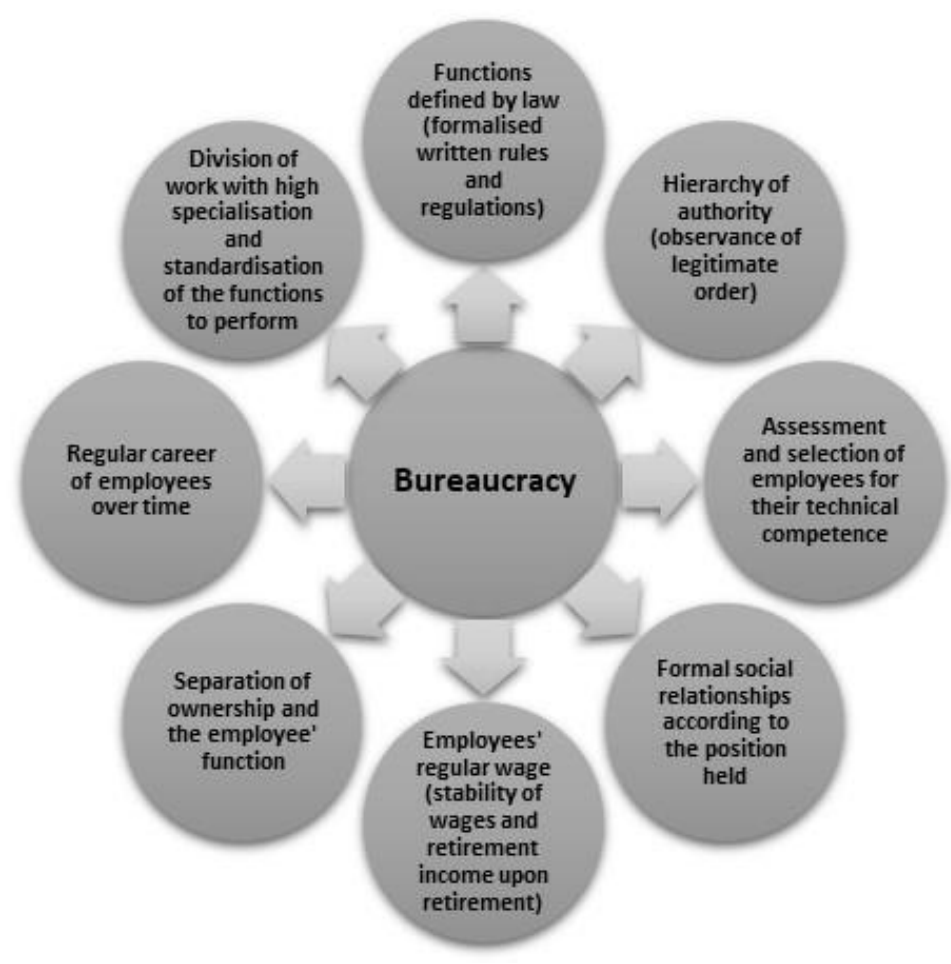

Figure 1. Characteristics of bureaucratic administration

Source: Adapted from Ferreira et al., 2004, pp. 24 and 25.

From the analysis of Weber's work, Julien Freund (1996) presents the following definition of bureaucracy for Max Weber:

Bureaucracy is the most typical example of legal domination. It is based on the following principles: 1 . The existence of defined services, and therefore of competences strictly determined by laws or regulations, in such a way that the functions are clearly divided and distributed, as well as the decision-making powers necessary for the accomplishment of the corresponding tasks; 2 . The protection of employees in the performance of their functions, by virtue of a statute (for example, the irremovability of judges). In general, those who become civil servants do so for life, so that the service of the State becomes the main profession rather than a secondary occupation, along with another profession; 3 . The hierarchy of functions, which means that the administrative system is heavily structured in subordinate services and management positions, with the possibility of appealing from the lower instance to the higher instance; in general, this structure is monocratic and not collegial and evidences a tendency toward maximum centralisation; 4. Recruitment takes place through tenders, exams or diplomas, which requires that candidates have specialised training. In general, the employee is appointed (seldom elected) on the basis of free selection and contractual commitment; 5 . The employee's wage in the form of a fixed salary and a retirement when he/she leaves the service of the State. The salaries are ranked according to the internal hierarchy of the administration and the importance of the responsibilities; 6 . The right of the authority to control the work of its subordinates, possibly through the establishment of a disciplinary committee; 7 . The possibility of employees' promotion on the basis of objective criteria and not at the discretion of the authority; 8 . The complete separation between the function and the individual who performs it, since no employee can be the owner of his/her position or of the means of the administration (Aron, 1994, p. 550).

For Weber, impersonality and formality, ensured by bureaucratic rationalisation, guarantee that organisational objectives are not confused with personal motivations or other interests (Godoi et al., 2017). Impersonality and formality allow dealing with situations and not exactly with people, treating all in the same formal way (Cruz, 1995). Furthermore, it would increase predictability in the functioning of any organisation (Ferreira, 2004; Filleau \& Marques-Ripoull, 2002).

The accomplishment of this aim entailed the emphasis on bureaucracy as administration, on the one hand, based on specialisation and, on the other hand, based on discipline. In the first component, obedience is invoked as a means to the achievement of an end; the individual obeys in part because of his/her feelings about the norm. In the second component, obedience would be an end in itself; the individual obeys the order mainly because of the position held by 
the person that orders, regardless of his/her feelings regarding the norm or order (Gouldner, 1966, p. 57).

Thus, Gouldner (1966) suggests that Weber implicitly referred not to one but to two types of bureaucracy: the «representative form of bureaucracy», based on the rules laid down by agreement and technically justified and administered by specialists; and a second type called «punitive bureaucracy», based on the imposition of norms and on pure and simple obedience (Gouldner, 1966, p. 58).

\subsection{Challenges of the Bureaucracy Ideal-type}

\section{Positive aspects}

For Weber, the irresistible diffusion of bureaucracy resulted from its purely technical superiority, in comparison with the remaining forms of organisation:

Precision, speed, clarity, knowledge of the archives, continuity, discretion, unity, strict subordination, reduction of friction and costs with material and personnel - are brought to the optimum level in the strictly bureaucratic administration, especially in its monocratic form [...] bureaucracy is "dehumanized" insofar as it manages to eliminate from official business love, hate, and all the personal, irrational, and emotional elements that escape calculation. This is the specific nature of bureaucracy, praised as its special virtue (Weber, 1982 [1948], pp. 249-251).

The bureaucratic administration was the most efficient of organisations, and as an ideal-type, the closer the bureaucracy is, the more effective and efficient the organisation will be in its standardised functioning (Giddens, 1997; Ferreira, 2004), being this ideal-type a historical form of rationality and scientificity (Ferreira, 2004). Weber referred to efficiency as a complex of values and procedures that included quality of behaviour (e.g. speed, uniformity of action), extent of the field of action, and effectiveness of operation costs (Beetham, 1988, p. 28). Some examples of bureaucracy efficiency according to Weber are the following: decisions and their procedures based on general criteria; an average level of competence in interpreting the law thanks to the training provided; full-time remuneration reduces the temptation of corruption; assessment by public exams that increases its justice (Giddens, 1997), basing its functioning on the experience of specialised professionals (Godoi et al., 2017).

\section{Negative aspects}

Although Weber advocated the technical superiority over other forms of organisation and management, bureaucracy was a human creation, although fatally compromised by its technical functioning, and individuals rapidly lost their control (Clegg, 1990):

Nowadays, rational calculation is present in any activity. Through it [...] each man becomes a cogwheel of the machine and, aware of this, his/her main desire is to become a bigger cogwheel [...] it is horrible to think that the world may one day be filled by these small cogwheels, small men clinging to small jobs and thirsting for the biggest [...] this passion for bureaucracy is enough to drive a person to despair (Weber, cit. in Mayer, 1956; Clegg, 1990).

Consequently, dysfunctions emerge in the functioning of the bureaucratic organisation (Filleau \& Marques-Ripoull, 2002; Cour, 2018), in the interpretation of the law (Pimentel, 2012), as well as the informal dimension, which "tend to originate a large number of unofficial forms of acting. In part, this takes place because the lack of flexibility can be gained by unofficial adjustments of the formal rules" (Giddens, 1997, p. 355). Ultimately, the rule functions as an end in itself (Giddens, 1997; Branco, 2017).

It is thus normal for the whole organisation to experience a tension between the ideal of rationality - clear objectives, efficacy, regulation, planned change - and the reality of the actors' practices and functioning. They are not devoid of rationality or coherence but are prisoners of multiple logics, a culture, a habitus, inheritances and multiple constraints (Perrenoud, 1994, p. 142).

Yet, Weber presents a solution to the potential dysfunctionalities generated by bureaucracy. For the author, "an employee who receives a directive which he/she believes is erroneous can and should object to it" (Weber 1997, p. 51, cit. in Godoi et al., 2017, p. 436).

Hence, the greater the professionalism in the organisation, in the Weberian view of bureaucratic rationalisation, the greater the guarantee that there is a bigger governance of this organisation. A vision poorly explored in the literature is this positive empowerment assimilated by the professionals of an organisation (Godoi et al., 2017, p. 442).

This is thus an aspect that deserves further development. 


\section{Other challenges}

A reifying conception of the notion of bureaucracy implies that it is a condition that is present or absent, assuming that organisations are either totally bureaucratic or non-bureaucratic, obscuring a perspective that emphasises bureaucracy as a form of organisation that exists across a number of dimensions, each one in the form of a continuum (Hall, 1966). Considering bureaucracy as an ideal-type can make it possible to determine in which particular aspect an organisation is bureaucratised. Hence, the notion of bureaucracy, the way it is often used, may not be that rational form described by Weber, but particular configurations of the bureaucratic model may be the most rational form for particular activities (Hall, 1966).

In the organisational configurations proposed by Mintzberg, two types of bureaucratic configurations are identified: the mechanical and the professional. The mechanical bureaucracy configuration is characterised by high complexity, formalisation and centralisation; it seeks to achieve efficiency by prioritising the standardisation of procedures to control highly divided and specialised work, and it works better in simple and stable environments. This configuration is composed of all the elements of the structure, in which the technostructure, the logistical support and the extensive hierarchical line are to be highlighted. Its main coordination mechanism is the standardisation of the work processes. The organisation's key substructure is the technostructure, which ensures the coordination and designs the rules and norms that govern the organisation.

The professional bureaucracy configuration is characterised by the predominance of the operational centre, a small hierarchical line and an equally small technostructure, but extensive logistical support. Coordination is based on the standardisation of qualifications, which are generally attained outside the organisation. The professionals have high control over their own work. It combines standardisation with decentralisation. The main coordination mechanism is the standardisation of qualifications. The main design parameters are training, horizontal specialisation of work and horizontal and vertical decentralisation (Mintzberg, 1995).

\section{Conclusion}

Bearing in mind that any organisational model presents limitations for the analysis and administration of an always complex object, the organisation (Rosado, 2015; Serpa, 2016; Cunha \& Cunha, 2002; Cour, 2018), the goal of this paper was to analyse the structure rationalisation in the proposal of Max Weber in the search of reduction of this complexity and uncertainty (Florian, 2018). It is concluded that the influence of the bureaucratic ideal-type can still be and is very useful nowadays (Rost \& Graetzer, 2014), but it is often criticised superficially as Godoi et al. (2017) show very well.

But care must be taken not to be tempted to propose universal recipes (Filleau \& Marques-Ripoull, 2002; Pollitt, 2009):

no human organisation is regulated like a clock, which is simultaneously its weakness and its strength. Its weakness, because that covers an important part of eventualities, of malfunctions, of uncertainties. Its strength, because the organisation continues to operate despite a considerable number of disorders and inconsistencies (Perrenoud, 1994, 156).

However, at the same time, the Weberian bureaucracy still presents a source of great wealth and relevance, if analysed in a critical way for contemporaneity (Florian, 2018; Godoi et al., 2017), which reveals that, at least for this specific concept,

the history of Human Sciences is not a graveyard of dead ideas. Some continue to live in us. Mistakes and deadlocks were plentiful, and promising clues were eliminated. We have learned a great deal, but we have forgotten much, too. And not everything that has taken place is outdated (Dortier, 2009, p. 15).

\section{Acknowledgements}

We would like to thank to the Reviewers for their comments and suggestions.

\section{Funding}

University of the Azores, Interdisciplinary Centre of Social Sciences-CICS.UAc/CICS.NOVA.UAc, UID/SOC/04647/2013, with the financial support of the FCT/MEC through national funds and when applicable co-financing from FEDER under the PT2020 Partnership Agreement.

\section{Conflict of interest}

The authors declare that there is no conflict of interest. 


\section{References}

Ang, Y. Y. (2016). Beyond Weber: Conceptualizing an alternative ideal type of bureaucracy in developing contexts. Regulation \& Governance, 11(3), 282-298. https://doi.org/10.1111/rego.12123

Aron, R. (1994). As etapas do pensamento sociológico [The stages of sociological thinking]. Lisboa: Publicações Dom Quixote.

Beetham, D. (1988). A burocracia [Bureaucracy]. Lisboa: Editorial Estampa.

Branco, P. H. V. B. C. (2016). Burocracia e crise de legitimidade: A profecia de Max Weber [Bureaucracy and crisis of legitimacy: The prophecy of Max Weber]. Lua Nova: Revista de Cultura e Política, (99), 47-77. https://doi.org/10.1590/0102-6445047-077/99

Clegg, S. (1990). Modern organizations: Organization studies in the postmodern world. London: Sage.

Cour, A. (2018). Organisation and interaction. Sociol Int J., 6(2), 404-409. DOI: 10.15406/sij.2018.02.00077

Cruz, M. B. da (1995). Teorias sociológicas. Os fundadores e os clássicos [Sociological theories. The founders and the classics]. Lisboa: Fundação Calouste Gulbenkian.

Cunha, M. P., \& Cunha, J. V. (2002). Improviso nas organizações. In Miguel P. Cunha \& S. Br. Rodrigues (Orgs), Manual de estudos organizacionais. Temas de psicologia, psicossociologia e sociologia das organizações [Handbook of organisational studies. Topics of psychology, psychosociology and sociology of organiaations] (pp. 155-165). Lisboa: RH Editora.

Cunha, M. P., \& Rodrigues, S. B. (2002). Manual de estudos organizacionais. Temas de psicologia, psicossociologia e sociologia das organizações [Handbook of organisational studies. Topics of psychology, psychosociology and sociology of organisations]. Lisboa: RH Editora.

Dortier, J. F. (Dir). (2009). Uma história das Ciências Humanas [A history of Human Sciences]. Lisboa: Edições Texto \& Grafia.

Faria, J. H. de, \& Meneghetti, F. K. (2011). Burocracia como organização, poder e controle [Bureaucracy as organisation, power and control]. ERA, 51(5), 424-439. https://doi.org/10.1590/S0034-75902011000500002

Fedosov, V., \& Paientko, T. (2017). Ukrainian government bureaucracy: Benefits and costs for the society. Business and Management Studies, 3(2), 8. https://doi.org/10.11114/bms.v3i2.2358

Ferreira, J. M., Neves, J., \& Caetano, A. (Coords.) (2004). Manual de psicossociologia das organizações [Handbook of psychosociology of organisations]. Lisboa: McGraw-Hill.

Ferreira. J. M. C. (2004). Abordagens clássicas [Classic approaches]. In J. M. Ferreira, J. Neves, \& A. Caetano (Coords.) Manual de psicossociologia das organizações [Handbook of psychosociology of organisations] (pp. 3-27). Lisboa: McGraw-Hill.

Filleau, M. G., \& Marques-Ripoull, C. (2002). Teorias da organização e da empresa: Das correntes fundadoras às práticas actuais [Organisation and company theories: From foundational currents to presente-day practices]. Oeiras: Celta Editora.

Florian, M. (2018). Unlikely allies: Bureaucracy as a cultural trope in a grassroots volunteer organization. Scandinavian Journal of Management, 34(2), 151-161. https://doi.org/10.1016/j.scaman.2018.03.002

Giddens, A. (1997). Sociologia [Sociology]. Lisboa: Fundação Calouste Gulbenkian.

Godoi, A., Silva, L. F., \& Cardoso, O. O. (2017). Ensaio teórico sobre a burocracia em Weber, o conflito da agência e a governança corporativa: Uma reflexão sobre a burocracia profissionalizante [Theoretical essay on bureaucracy in Weber, the agency conflict and corporate governance: A reflection on professional bureaucracy]. Revista de Administração de Roraima-UFRR, 7(2), 426-447. https://doi.org/10.18227/2237-8057rarr.v7i2.4034

Gouldner, A. (1966). Conflitos na teoria de Weber. [Conflicts in Weber's theory]. AAVV. Sociologia da burocracia. Rio de Janeiro: Zahar Editores.

Guzmán, J. P. H. (2015). El Estado en la sociedad, explicación de cómo la disposición de las burocracias determina los órdenes en países periféricos [The State in society, an explanation of how the arrangement of bureaucracies determines the orders in peripheral countries]. Panorama, 9(17), 104-122. https://doi.org/10.15765/pnrm.v9i17.795

Hall, R. (1966). O conceito de burocracia: Uma contribuição empírica [The concept of bureaucracy: An empirical contribution]. AAVV. Sociologia da Burocracia. Rio de Janeiro: Zahar Editores

Matos, F. R. N., \& Lima, A. F. (2007). Organizações modernas e a burocracia: Uma “afinidade eletiva”? [Modern 
organisations and bureaucracy: An "elective affinity"?] USP RAE, 6(2), Available at http://www.rae.com.br/eletronica/index.cfm?FuseAction=PENSATA\&ID=4669\&Secao=ARTIGOS\&. https://doi.org/10.1590/s1676-56482007000200008

Mayer, J. (1956). Max Weber and German politics. London: Faber \& Faber.

Mintzberg, H. (1995). Estrutura e dinâmica das organizações [Structure and dynamics of organisations]. Lisboa: Publicações D. Quixote.

Paiva, A. (2014). Pensamento sociológico. Uma introdução didática às teorias clássicas [Sociological thought. A didactic introduction to classical theories]. Lisboa: PACTOR - Edições de Ciências Sociais, Forenses e da Educação.

Perrenoud, P. (1994). A organização, a eficácia e a mudança, realidades construídas pelos actores [The organiaation, effectiveness and change, realities built by the actors]. In M. G. Thurler, \& P. Perrenoud (Eds.), A escola e a mudança. Contributos sociológicos [School and change. Sociological contributions] (pp. 133-159). Lisboa: Escolar Editora.

Pimentel, D. (2012). Sociologia da empresa e das organizações. Uma breve introdução a problemas e perspectivas [Sociology of de company and organisations. A brief introduction to problems and perspectives]. Lisboa: Escolar Editora.

Pollitt, C. (2008). Bureaucracies remember, post-bureaucratic organizations forget? Public Administration, 87(2), 198-218. https://doi.org/10.1111/j.1467-9299.2008.01738.x

Rosado, D. P. (2015). Sociologia da gestão e das organizações [Sociology of management and organisations]. Lisboa: Gradiva.

Rost, K., \& Graetzer, G. (2014). Multinational organizations as rule-following bureaucracies - The example of catholic orders. Journal of International Management, 20(3), 290-311. https://doi.org/10.1016/j.intman.2013.11.001

Serpa, S. (2018). Ideal type in sociological research. Sociology International Journal, 2(5). https://doi.org/10.15406/sij.2018.02.00075

Serpa, S. N. (2016). Organization as an analytical level for investigation organizational culture. The Social Sciences, 11, 3257-3263. http://medwelljournals.com/abstract/?doi=sscience.2016.3257.3263.

Souza, E. M. D. (2017). Where is queer theory in organizational studies? Sociol Int J., 1(4), $127-134$. https://doi.org/10.15406/sij.2017.01.00021

Touraine, A. (1988). Modernity and cultural specificities. International Social Science Journal, 118, 443-457.

Wagner, P. (1997). Sociología de la modernidad [Sociology of modernity] Barcelona: Herder.

Weber, M. (1966). Os fundamentos da organização burocrática: Uma construção do tipo ideal [The basics of bureaucratic organization: A construction of the ideal type]. AAVV. Sociologia da Burocracia. Rio de Janeiro: Zahar Editores.

Weber, M. (1982). Ensaios de sociologia [Sociology essays]. Organisation and introduction by H. Gerth and C. Wright Mills. Rio de Janeiro: Editora Guanabara.

\section{Copyrights}

Copyright for this article is retained by the author(s), with first publication rights granted to the journal.

This is an open-access article distributed under the terms and conditions of the Creative Commons Attribution license which permits unrestricted use, distribution, and reproduction in any medium, provided the original work is properly cited. 